\title{
A Chemical Mutagenesis Approach to Insert Post-Translational Modifi- cations in Aggregation-Prone Proteins
}

\author{
Ying Ge, Athina Masoura, Jingzhou Yang, Francesco A. Aprile* \\ Department of Chemistry, Molecular Sciences Research Hub, Imperial College London, London W12 OBZ, United Kingdom
}

KEYWORDS: Post-translational modification, chemical mutagenesis, amyloid- $\beta$, Alzheimer's disease.

\begin{abstract}
Neurodegenerative diseases are a class of disorders linked to the formation in the nervous system of fibrillar protein aggregates called amyloids. This aggregation process is affected by a variety of post-translational modifications, whose specific mechanisms are not fully understood yet. Emerging chemical mutagenesis technology is currently striving to address the challenge of introducing protein post-translational modifications, while maintaining proteins stable and soluble during the modification reaction. Several amyloidogenic proteins are highly aggregation-prone, and current modification procedures lead to unexpected precipitation of these proteins, affecting their yield and downstream characterization. Here, we present a method for maintaining amyloidogenic proteins soluble during chemical mutagenesis. As proof-of-principle, we applied our method to mimic the phosphorylation of the serine 26 and the acetylation of the lysine 28 of the 40 -residue long variant of amyloid- $\beta$ peptide, whose aggregation is linked to Alzheimer's disease.
\end{abstract}

\section{Introduction}

Dementia is an umbrella term that refers to several pathologies characterized by progressive and irreversible damages to the nervous system. They are a major cause of morbidity and mortality across the globe, with over 78 million people estimated to be affected by 2030 worldwide. ${ }^{1}$ Alzheimer's disease (AD), the most common form of dementia, is distinguished by disease hallmarks including amyloid- $\beta(A \beta)$ plaques and tau-containing neurofibrillary tangles. ${ }^{2,3} \mathrm{~A} \beta$ is an aggregationprone peptide produced from aberrant cleavage of the amyloid precursor protein (APP), an integral membrane protein abundant at the synapses, by the sequential proteolytic cleavage of the $\beta$ - and $\gamma$-secretases. ${ }^{4}$ Genetic mutations of APP and of the secretase genes promoting this proteolytic pathway and are linked to familial AD. ${ }^{5-7}$ Furthermore, most cases of AD are sporadic and post-translational modifications (PTMs) can be induced by environmental factors such as inflammation. ${ }^{8}$ PTMs including truncation, serine phosphorylation, lysine acetylation, methionine oxidation and polyglutamylation are found in $\mathrm{A} \beta$ aggregates, with reported effects such as increasing or reducing the rate of aggregation and plaque formation. ${ }^{2,8} \mathrm{Howev}^{-}$ er, detailed biomolecular and mechanistic studies of each PTM is hindered by the lack of site-specific tools to introduce them. To date, PTMs in A $\beta$ have been generated by solid-state peptide synthesis, ${ }^{9-11}$ enzymatic reaction, ${ }^{12,13}$ and non-site specific chemical modification. ${ }^{14}$ However, these methods have their drawbacks. Solid-state synthesis is costly. Enzymatic reactions are limited in scope, whilst chemical modifications tend to react with multiple residues of the same type. In contrast, site-specificity and product versatility can be combined using a dehydroalanine (Dha)-based method of introducing PTM mimetics developed by Davis and co-workers. ${ }^{15,16}$ Briefly, cysteine is converted to Dha via an alkylation-elimination reaction with a dibromide compound, allowing subsequent Michael addition with a variety of thiol-containing compounds. As cysteine can be introduced via molecular cloning techniques, installation of PTMs can be carried out in a site-specific yet versatile manner.

This method has been applied to histone $\mathrm{H} 3,15,16$ as well as to a single-domain antibody and the amyloidogenic protein Tau. ${ }^{17,18}$. However, additional challenges are faced in the modification of $A \beta$ due to its hydrophobic and aggregation-prone nature. Procedures required for the chemical reactions, such as heating and shaking, could lead to protein precipitation and aggregation, thus reducing the yield and limiting downstream application. Here, we establish a facile, high-yield protocol of introducing PTM mimetics in A $\beta$, while maintaining the peptide soluble, by utilizing a solubility-enhancing domain..$^{19}$ As a proof of concept, we installed mimetics of two PTMs: phosphorylation of S26 and acetylation of K28. K28 has been reported to form salt bridge with D23 in A $\beta 40,11,20$ and with the carboxyl group of A42 in A $\beta 42,{ }^{21}$ although $K 28$ acetylation only had a limited effect on the aggregation of $A \beta 42 .{ }^{10}$ In contrast, S26 phosphorylation in $A \beta 40$, which results in an alternative pS26K28 salt bridge, appears to promote the accumulation of cytotoxic oligomeric species while reducing the formation of fibrils, leading to a reduction of fluorescence intensity in Thioflavin T (ThT) and Congo red assays ${ }^{11,13}$ By successfully introducing mimetics of these two PTMs, we overcome the unique difficulties of carrying out chemical biology on a peptide with a high propensity to aggregate. We also demonstrate that the aggregation behaviors of these peptides agree with previous re- 
bioRxiv preprint doi: https://doi.org/10.1101/2022.01.28.478135; this version posted January 28, 2022. The copyright holder for this preprint

(which was not certified by peer review) is the author/funder. All rights reserved. No reuse allowed without permission.

ports. ${ }^{10,11,13}$ This method can be readily adapted to introduce other types of PTMs in A $\beta$ and enable a wide range of biophysical studies.

\section{Results and Discussion}

Experimental Strategy. A $\beta 40$ and its cysteine variants are expressed in Escherichia coli (E. coli) as a fusion protein with spider silk protein domain (SD) as previously reported. ${ }^{19}$ Purification and modification are carried out on the fusion protein (Figure 1), as we theorize that enhanced solubility afforded by the SD would allow multiple steps of chemical modification to be carried out on $A \beta$. First, SD-A $\beta 40$ (or variant) is purified under reducing condition using affinity chromatography, via its $\mathrm{N}$-terminal His 6 tag. As there is no cysteine present in $\mathrm{A} \beta 40$ natively, the introduced cysteine can be site-specifically converted to Dha by reacting with of 2,5-Dibromohexanediamide (DBHDA). Dha26 is subsequently converted to phosphoserine mimetic phosphocysteine ( $\mathrm{pC}$ ) by reaction with sodium thiophosphate, while Dha28 is reacted with $\mathrm{N}$-acetylcysteamine to mimic acetyllysine. The resulting residue is hereafter referred to as Ac(S)K28 as the sidechain C $\beta$ of lysine is substituted with S. Finally, the addition of Tobacco Etch Virus (TEV) protease separates the SD from A $\beta$, and size-exclusion chromatography (SEC) enables the removal of SD to obtain modified $A \beta$.

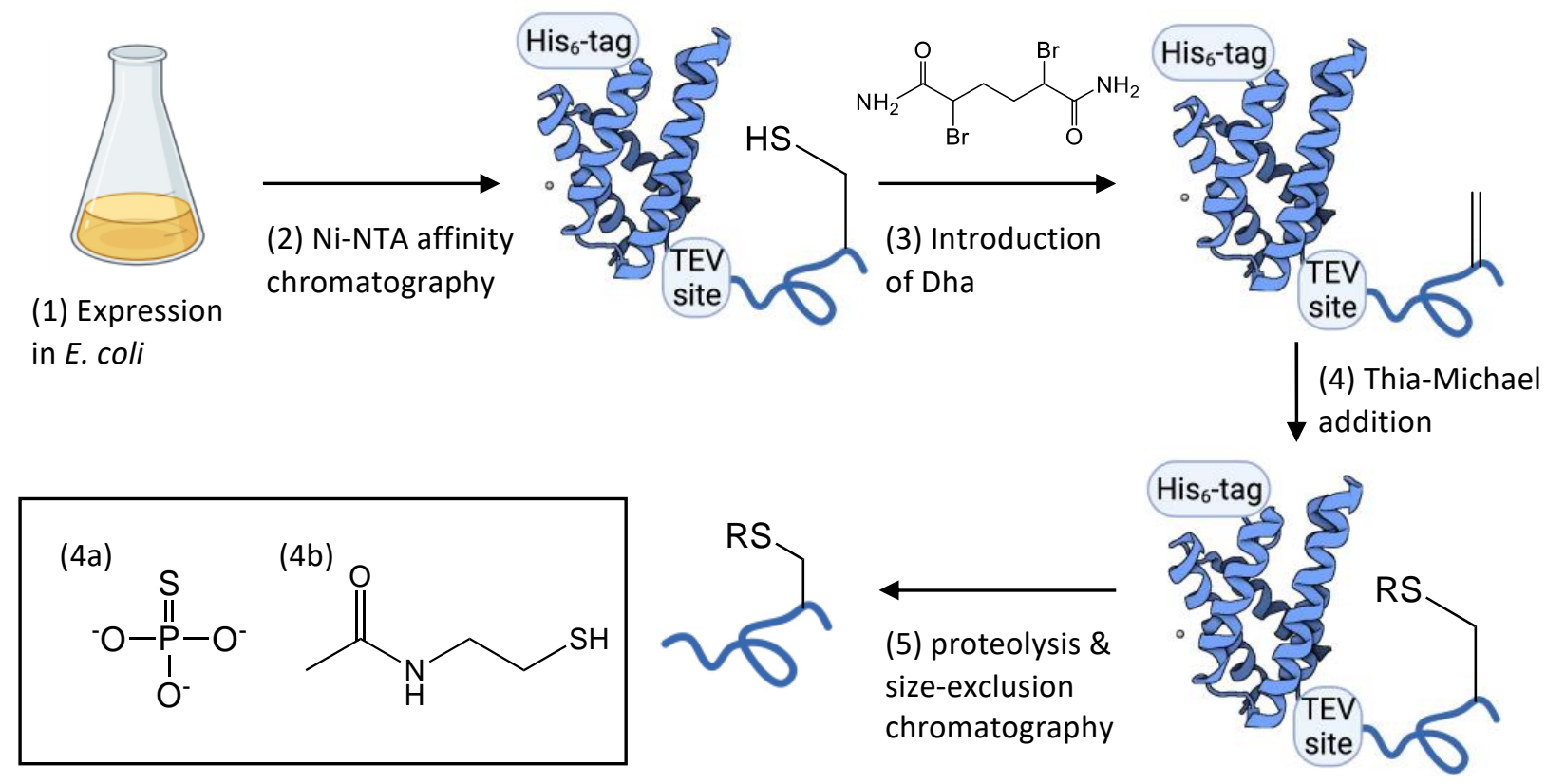

Figure 1 Experimental Strategy. (1) SD-A $\beta 40$ with a single cysteine is expressed as a His6-tagged fusion protein in E. coli BL21(DE3) cells. (2) The fusion protein is purified from the cell lysate by Ni-NTA affinity chromatography. (3) Purified fusion protein is reacted with DBHDA to convert the cysteine residue into a Dha. (4) Dha is then converted into phosphocysteine or acetyllysine mimic by thia-Michael addition with sodium thiophosphate $\left(4 \mathrm{a}, \mathrm{R}=\mathrm{PO}_{3}\right)$ or $\mathrm{N}$-acetylcysteamine $\left(4 \mathrm{~b}, \mathrm{R}=\mathrm{C}_{4} \mathrm{H}_{8} \mathrm{NO}\right)$, respectively. (5) The SD is removed via proteolysis by the addition of TEV protease, and the digestion mixture was subjected to size-exclusion chromatography to remove the SD and TEV, and to obtain monomeric A $\beta$.

Introduction of Dha and PTM mimetics to SD-Aß40. SD-A $\beta 40-S 26 \mathrm{C}$ and SD-A $\beta 40-\mathrm{K} 28 \mathrm{C}$ were purified as a fusion protein by Ni-NTA affinity chromatography. Mass spectrometry (MS) confirmed the serine/lysine to cysteine mutations, as the observed mass matches that of the expected fusion protein minus an N-terminal methionine, which is thought to have been lost during purification or MS analysis (Figure 2A, 2E and S1, S5). In SD-A $340-K 28 C$, an additional peak with a +75 Da mass shift was observed (Figure 2E and S5), which may be a BME-adduct resulted from the purification process, and disappears after modification with DBHDA (Figure 2F and S6). A mass shift of -34 Da was observed (Figure 2B, 2F and S2, S6) following incubation of the protein with DBHDA at $37^{\circ} \mathrm{C}$ for $3 \mathrm{~h}$, indicating the conversion of the cysteine into Dha. For the final modification step, SD-A 340 -Dha26 was reacted with sodium thiophosphate, resulting in a mass shift of +80 Da compared to SDA $340-S 26 C$, (Figure 2C and S3) in accordance with the formation of pC. For SD-A 340 -Dha28, the formation of an acetyllysine mimic was observed after incubation with $\mathrm{N}$-acetylcysteamine (Figure $2 \mathrm{G}$ and $\mathrm{S7}$ ). 


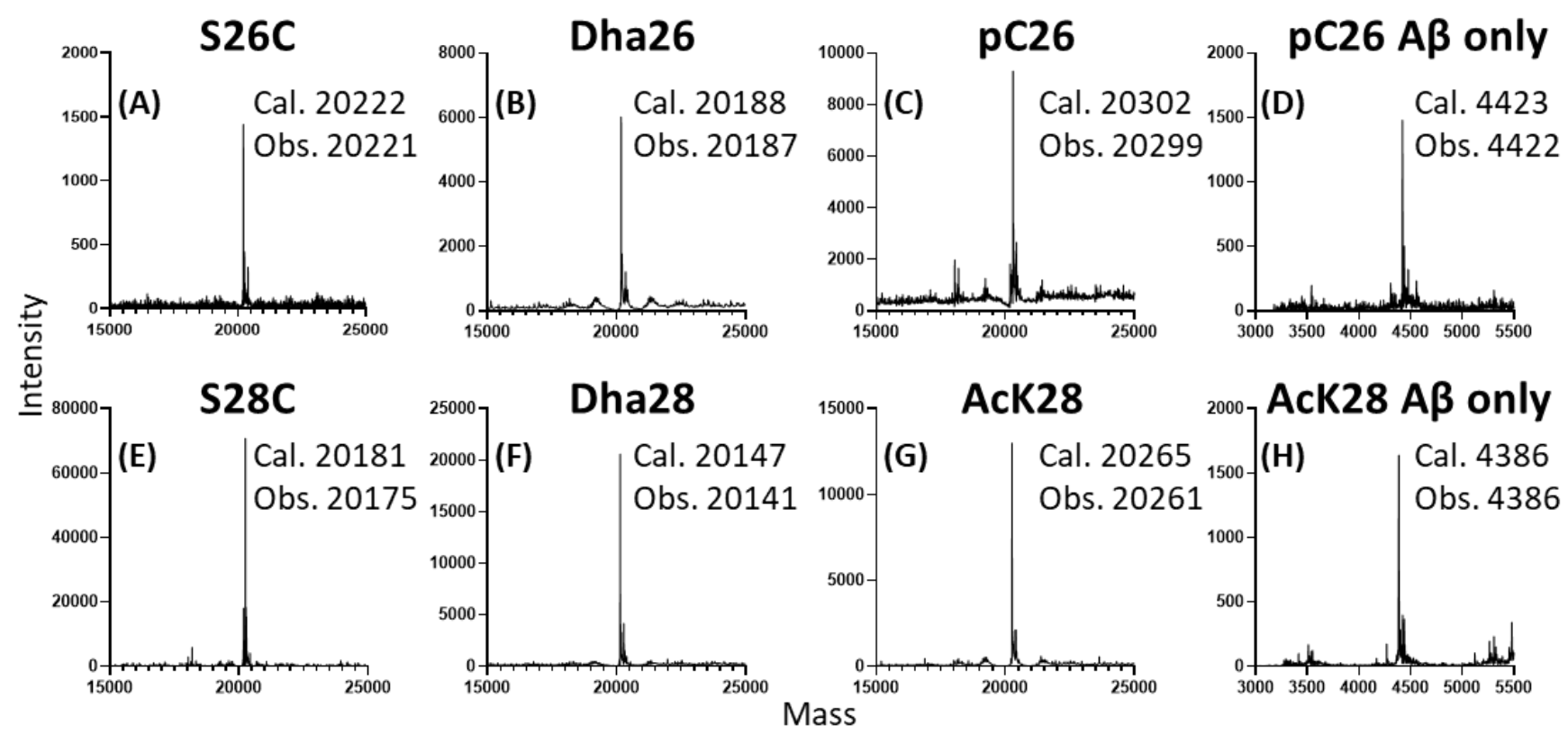

Figure 2 Chemical mutagenesis of SD-A 340 . (A-C) Deconvoluted mass spectra of SD-A $340-S 26 C$ with C26 (A), Dha26 (B) and pC26 (C), showing calculated and observed mass of each variant. (D) Deconvoluted mass spectrum of A $\beta 40$-pC26 after TEV cleavage and SEC purification. (E-G) Deconvoluted mass spectra of SD-A340-K28C with C28 (E), Dha28 (F) and Ac(S)K28 (G). (H) Deconvoluted mass spectrum of A 340 -AcK28 after TEV cleavage and SEC purification. Cal., calculated; Obs., observed.

Purification of Monomeric Aß40 variants. To produce authentic (i.e., with no overhanging initial methionine) A $\beta 40$ peptide without the SD, the fusion protein was incubated with TEV protease to remove the N-terminal silk domain (Figure 1 , Figure 3A). The resulting peptide begins with an aspartic acid, same as naturally occurring A $\beta$ peptides. The proteolyzed sample was subjected to SEC and fractions containing purified A $\beta$ peptides are collected for subsequent characterization (Figure 3). MS analysis shows A 340 peptide at the expected mass with high homogeneity (Figure 2D, 2H and S4, S8), confirming that the modifications remain stable after removal of the silk domain by TEV protease cleavage and the SEC process.

Comparison of the aggregation behaviors of $A \beta 40, A \beta 40-p C 26$ and $A \beta 40-A c(S) K 28$. ThT assays were carried out to compare the aggregations of $\mathrm{A} \beta 40, \mathrm{~A} \beta 40-\mathrm{pC} 26$ and $\mathrm{A} \beta 40-\mathrm{Ac}(\mathrm{S}) \mathrm{K} 28$ to determine whether our modifications have consistent effects with the PTMs of which they are mimetics. The ThT kinetic of A $340-\mathrm{Ac}(\mathrm{S}) \mathrm{K} 28$ was slower but overall comparable to that of $A \beta 40$ (Figure 3B). This observation agrees with a previous study of A $\beta 42$, where K28 acetylation had limited effect on the protein aggregation rate. ${ }^{10}$ Transmission electron microscopy (TEM) on samples taken at the plateau of the aggregation showed long, thin fibrils for A $\beta 40$ (Figure 3C). Shorter, heavily clustered fibrils were observed for A $\beta 40-A c(S) K 28$ (Figure $3 \mathrm{~B}$ ), suggesting that K28 acetylation may affect the morphology of aggregates. In contrast, A $440-p C 26$ showed a slow, close-to-linear increase in ThT fluorescence (Figure 3B), similar to solid-phase synthesized A $440-p S 26 .{ }^{11,13} \mathrm{~A}$ lack of fibrillar aggregates observable by TEM in A 440 -pC26 samples after incubation (Figure 3C) confirms the disruption to fibrillization caused by phosphorylation of residue 26.

The current study is a proof of concept of a strategy to post-translationally modify in a site-specific manner aggregationprone proteins. Although the final products are likely an epimeric mixture due to the planar conformation of Dha, several works have demonstrated the suitability of these PTM mimetics as research tools. Histone H3 containing pC generated via the Dha intermediate were shown to respond to pS-specific antibodies, and to be substrates of phosphatases. ${ }^{16}$ Installing pC at S356 of tau results in the inhibition of tubulin polymerization, an effect also observed when S356 is phosphorylated by other methods. ${ }^{18}$ Our results further demonstrated that PTMs mimetics introduced via the Dha-intermediate can be used to study the effect of the corresponding PTMs on protein aggregation. 
bioRxiv preprint doi: https://doi.org/10.1101/2022.01.28.478135; this version posted January 28, 2022. The copyright holder for this preprint (which was not certified by peer review) is the author/funder. All rights reserved. No reuse allowed without permission.

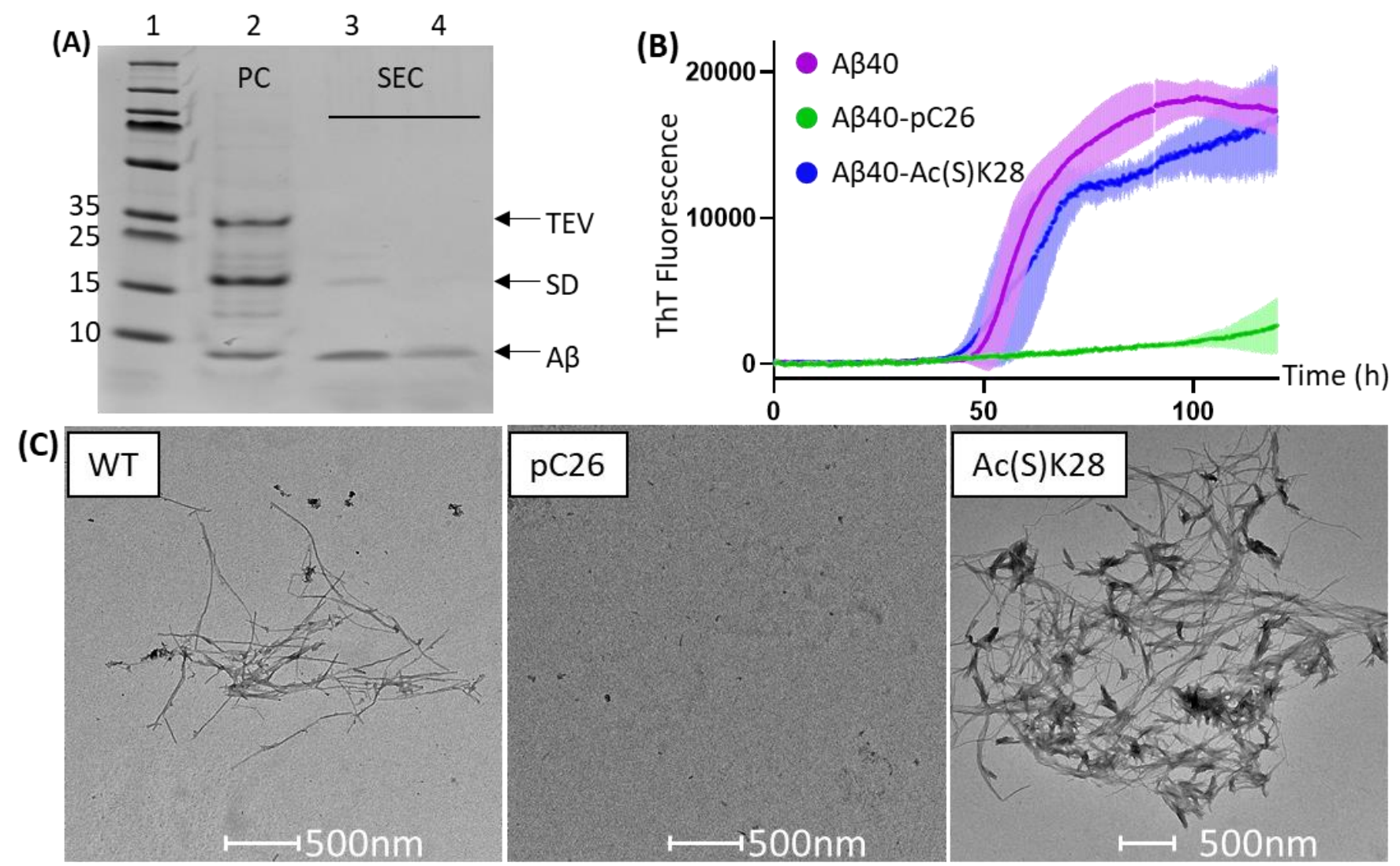

Figure 3 (A) Representative SDS-PAGE showing the purification of A $\beta 40$ (or PTM variants) from the fusion protein-TEV reaction mix. Lane 2, SD-A 340 TEV reaction mixture (PC, pre-column). Following each SEC purification multiple fractions are collected and the purest (in this case lane 4) are used in aggregation assays. (B) ThT aggregation assay of $5 \mu \mathrm{M}$ recombinant A $\beta 40$ (magenta), A 340 -pC26 (green) or A $340-A c(S) K 28$ (blue) peptides, and. Fluorescence of $20 \mu \mathrm{M}$ ThT in buffer alone was recorded in parallel and subtracted as baseline. Error bars show standard deviation $(\mathrm{N}=5)$. Inset shows the aggregation of $\mathrm{A} \beta 40$-pC26. (C) TEM images showing long, thin fibrils observed in A $\beta 40$, no fibrils in A $\beta 40-p C 26$, and shorter, clustered fibrils in $A \beta 40-A c(S) K 28$ after $163 \mathrm{~h}$ of incubation at $37^{\circ} \mathrm{C}$.

\section{Methods}

Cloning, Protein Expression and Purification of the Silk Domain Aß40 Fusion Proteins. The mutations S26C and K28C were introduced to SD-A 40 fusion protein ${ }^{19}$ via site-directed mutagenesis using a QuikChange Lightning Kit (Agilent, USA) following a modified protocol. ${ }^{22}$ The successful introduction of mutations was confirmed by sequencing (Genewiz). Chemically competent $E$. coli BL21(DE3) cells were transformed with the wildtype or mutated plasmids and used to overexpress proteins according to established protocol. ${ }^{19}$ Briefly, cells were cultured in LB-kanamycin medium at $37^{\circ} \mathrm{C}, 120 \mathrm{rpm}$ until OD600nm reached 0.8-0.9, when the temperature was lowered to $20^{\circ} \mathrm{C}$ and expression was induced by the addition of $0.1 \mathrm{mM}$ Isopropyl $\beta$-d-1-thiogalactopyranoside (IPTG). After incubation overnight, cells were harvested by centrifugation at $6000 \mathrm{~g}$ for $15 \mathrm{~min}$, and the pellets were frozen and thawed prior to re-suspension in binding buffer (8 M urea, $20 \mathrm{mM}$ Tris$\mathrm{HCl} \mathrm{pH} \mathrm{8.0,15} \mathrm{mM} \mathrm{imidazole)} \mathrm{and} \mathrm{sonication} \mathrm{at} 500 \mathrm{~W}, 20 \%$ amplitude for $10 \mathrm{~min}$ (15 s on, $45 \mathrm{~s}$ off). Cell lysate was cleared by centrifugation at 38,758 $\mathrm{g}$ and the supernatant was passed through a syringe filter with a diameter of $0.45 \mu \mathrm{m}$. The filtrate was applied to a HisTrap HP column (Cytiva) and the target protein was eluted with a mix of $40 \%$ binding buffer and $60 \%$ elution buffer (8 M urea, $20 \mathrm{mM}$ Tris- $\mathrm{HCl} \mathrm{pH} 8.0,300 \mathrm{mM}$ imidazole). The elute was collected and dialyzed against 50 $\mathrm{mM}$ phosphate buffer $\mathrm{pH} 8.0$ for 16 h. For cysteine-containing variants, binding and elution buffers were supplemented with $3 \mathrm{mM} \beta$-mercaptoethanol (BME). Protein concentrations were calculated using A280 nm values measured on a Nanodrop (Thermo Scientific) and extinction co-efficient values obtained from the Expasy ProtParam tool ${ }^{23}$.

Introduction of Dha. $2 \mathrm{mM}$ tris(2-carboxyethyl)phosphine (TCEP) and 400 molar equivalent of DBHDA was added to $200 \mu \mathrm{M}$ SD-A $340-\mathrm{S} 26 \mathrm{C}$ or SD- A $340-\mathrm{K} 28 \mathrm{C}$, and the reaction was incubated at $37^{\circ} \mathrm{C}$ with shaking at $400 \mathrm{rpm}$ for $3 \mathrm{~h}$. After the precipitate was removed by centrifugation, small molecules were removed by passing the sample through a HiTrap desalting column with Sephadex G-25 resin (Cytiva) pre-equilibrated in 0.1 M sodium phosphate buffer pH 8.0, or by dialysis. For mass spectrometry (MS) analysis (liquid chromatography electrospray, LC-ES), the samples were desalted using Zeba Spin columns (Thermo Scientific) with 7K MWCO. 
Generation of phosphocysteine. $480 \mathrm{mg}$ sodium thiophosphate $\left(\mathrm{NaSPO}_{3}\right)$ was dissolved in $186 \mu \mathrm{l} \mathrm{H}_{2} \mathrm{O}$ and $200 \mu \mathrm{l} 5 \mathrm{M}$ $\mathrm{HCl}$. This stock was added to $100 \mu \mathrm{M}$ Dha-containing protein (SD-A $\beta 40$-Dha26) at 1:5 volume ratio. Reactions were carried out at $37^{\circ} \mathrm{C}$ with shaking at $400 \mathrm{rpm}$ for $6 \mathrm{~h}$ in the presence of $1.5 \mathrm{M}$ urea. Excess salt was removed by dialysis in $0.1 \mathrm{M}$ sodium phosphate buffer pH 8.0 prior to TEV cleavage. For MS analysis, samples were desalted using Zeba Spin columns (Thermo Scientific) with 7K MWCO.

Generation of acetyllysine mimic. $50 \mu \mathrm{l}$ of N-Acetylcysteamine were added to $1.2 \mathrm{ml}$ of $100 \mu \mathrm{M}$ SD-A 340 -Dha28. Reactions were incubated at room temperature $\left(25^{\circ} \mathrm{C}\right)$ with shaking at $400 \mathrm{rpm}$ for $3 \mathrm{~h}$. Excess salt was removed by dialysis in $0.1 \mathrm{M}$ sodium phosphate buffer pH 8.0 prior to TEV cleavage. For MS analysis, samples were desalted using Zeba Spin columns (Thermo Scientific) with 7K MWCO.

Removal of the SD and Purification of the A $\mathbf{\beta} 40$ Variants. SD-A $\beta 40$ and variants were dialyzed against $0.1 \mathrm{M}$ phosphate buffer $\mathrm{pH} 8.0$ and the SD was cleaved from A $\beta 40$ by incubating with TEV protease at 20:1 molar ratio for $1 \mathrm{~h}$ at room temperature followed by $23 \mathrm{~h}$ at $4{ }^{\circ} \mathrm{C}$. After proteolysis the sample was dissolved in $6 \mathrm{M}$ guanidine- $\mathrm{HCl}$ and subjected to size exclusion chromatography on a Superdex 75 increase 10/300 GL column (Cytiva) pre-equilibrated in 20 mM phosphate buffer pH 8.0 supplemented with $200 \mu \mathrm{M}$ EDTA, to separate the A $\beta 40$ peptide from TEV and SD. Fractions were analyzed by SDS-PAGE and only those containing pure $A \beta$ were used for subsequent applications. Concentration is calculated from the UV absorption reading on an ÄKTA Pure protein purification system operated with the Unicorn 7 software. For MS analysis, the samples were buffer exchanged into $\mathrm{H}_{2} \mathrm{O}$ using an Amicon concentrator with 3K MWCO (Millipore).

ThT Aggregation Assay. A $\beta 40$ and PTM variants were mixed and incubated with $20 \mu \mathrm{M}$ ThT and $0.02 \%$ sodium azide at $37{ }^{\circ} \mathrm{C}$ without shaking in $20 \mathrm{mM}$ sodium phosphate buffer, $\mathrm{pH}$ 8.0, $200 \mu \mathrm{M}$ EDTA, in a black 96-well non-binding microplate with clear bottom (Greiner \#655906). Fluorescence was monitored in a CLARIOstar Plus plate reader with excitation filter of $440 \pm 10 \mathrm{~nm}$ and emission filter of $480 \pm 10 \mathrm{~nm}$.

Transmission Electron Microscopy. A $\beta 40$ and PTM variants were mixed and incubated with $20 \mu \mathrm{M}$ ThT and $0.02 \%$ sodium azide at $37{ }^{\circ} \mathrm{C}$ without shaking in $20 \mathrm{mM}$ sodium phosphate buffer, pH 8.0, $200 \mu \mathrm{M}$ EDTA. Samples were collected at $163 \mathrm{~h}$ of the incubation and deposited onto carbon-coated copper mesh grids and negatively stained with $2 \%$ (w/v) uranyl acetate. The samples were then viewed with a FEI Tecnai T12 Spirit $120 \mathrm{kV}$ transmission electron microscope.

\section{AUTHOR INFORMATION}

\section{Corresponding Author}

* To whom correspondence should be addressed: f.aprile@imperial.ac.uk

\section{Author Contributions}

Y.G and F.A.A designed the research. Y.G, A.M and J.Y performed the experiments. Y.G, A.M, J.Y and F.A.A analyzed the data. Y.G., A.M and F.A.A. wrote the manuscript.

\section{Funding Sources}

We thank UK Research and Innovation (Future Leaders Fellowship MR/S033947/1), the Alzheimer's Society, UK (Grant 511), and Alzheimer's Research UK (ARUK-PG2019B-020) for support.

Notes

The authors declare no competing financial interest.

\section{ACKNOWLEDGMENT}

MS analyses were carried out by Dr Lisa Haigh of the Chemistry Mass Spectrometry Facility, Imperial College London. We thank Dr Henrik Biverstål (Karolinska Institutet) for providing the expression plasmid for the silk domain-A 340 fusion protein.

\section{ABBREVIATIONS}

$\mathrm{A} \beta$, amyloid- $\beta$; AcK, acetyllysine; $\mathrm{Ac}(\mathrm{S}) \mathrm{K}$, thiol-containing mimic of AcK; AD, Alzheimer's disease; APP, amyloid precursor protein; BME, $\beta$-mercaptoethanol; DBHDA, 2,5-dibromohexanediamide; DTT, dithiothreitol; EDTA, ethylenediaminetetraacetic acid; IPTG, isopropyl $\beta$-D-1-thiogalactopyranoside; LC-ES, liquid chromatography electrospray; MS, mass spectrometry; pC, phosphocysteine; pS, phosphoserine; PTM, post-translational modification; SD, silk domain; SDS-PAGE, sodium dodecyl sulphate-polyacrylamide gel electrophoresis; SEC, size-exclusion chromatography; TCEP, tris(2-carboxyethyl)phosphine; TEM. Transmission electron microscopy; TEV, Tobacco Etch Virus; ThT, Thioflavin T. 
bioRxiv preprint doi: https://doi.org/10.1101/2022.01.28.478135; this version posted January 28, 2022. The copyright holder for this preprint (which was not certified by peer review) is the author/funder. All rights reserved. No reuse allowed without permission.

\section{REFERENCES}

(1) Alzheimer's Disease International. World Alzheimer Report 2021: Journey through the Diagnosis of Dementia; 2021.

(2) Jin, Y.; Vadukul, D. M.; Gialama, D.; Ge, Y.; Thrush, R.; White, J. T.; Aprile, F. A. The Diagnostic Potential of Amyloidogenic Proteins. Int. J. Mol. Sci. 2021, 22 (8), 4128. https://doi.org/10.3390/ijms22084128.

(3) Hansson, O. Biomarkers for Neurodegenerative Diseases. Nat. Med. 2021, 27 (6), 954-963. https://doi.org/10.1038/s41591-02101382-x.

(4) Murphy, M. P.; LeVine, H. Alzheimer's Disease and the $\beta$-Amyloid Peptide. J. Alzheimers Dis. JAD 2010,19 (1), 311. https://doi.org/10.3233/JAD-2010-1221.

(5) Nilsberth, C.; Westlind-Danielsson, A.; Eckman, C. B.; Condron, M. M.; Axelman, K.; Forsell, C.; Stenh, C.; Luthman, J.; Teplow, D. B.; Younkin, S. G.; Näslund, J.; Lannfelt, L. The "Arctic" APP Mutation (E693G) Causes Alzheimer's Disease by Enhanced A $\beta$ Protofibril Formation. Nat. Neurosci. 2001, 4 (9), 887-893. https://doi.org/10.1038/nn0901-887.

(6) Hendriks, L.; van Duijn, C. M.; Cras, P.; Cruts, M.; Van Hul, W.; van Harskamp, F.; Warren, A.; McInnis, M. G.; Antonarakis, S. E.; Martin, J.-J.; Hofman, A.; Van Broeckhoven, C. Presenile Dementia and Cerebral Haemorrhage Linked to a Mutation at Codon 692 of the $\beta$-Amyloid Precursor Protein Gene. Nat. Genet. 1992, 1 (3), 218-221. https://doi.org/10.1038/ng0692-218.

(7) Fernandez, M. A.; Klutkowski, J. A.; Freret, T.; Wolfe, M. S. Alzheimer Presenilin-1 Mutations Dramatically Reduce Trimming of Long Amyloid $\beta$-Peptides $(A \beta)$ by $\gamma$-Secretase to Increase 42-to-40-Residue A $\beta$. J. Biol. Chem. 2014, 289 (45), 31043-31052. https://doi.org/10.1074/jbc.M114.581165.

(8) Kummer, M. P.; Heneka, M. T. Truncated and Modified Amyloid-Beta Species. Alzheimers Res. Ther. 2014,6 (3), 28. https://doi.org/10.1186/alzrt258.

(9) Kumar, S.; Wirths, O.; Theil, S.; Gerth, J.; Bayer, T. A.; Walter, J. Early Intraneuronal Accumulation and Increased Aggregation of Phosphorylated Abeta in a Mouse Model of Alzheimer's Disease. Acta Neuropathol. (Berl.) 2013, 125 (5), $699-709$. https://doi.org/10.1007/s00401-013-1107-8.

(10) Adhikari, R.; Yang, M.; Saikia, N.; Dutta, C.; Alharbi, W. F. A.; Shan, Z.; Pandey, R.; Tiwari, A. Acetylation of Aß42 at Lysine 16 Disrupts Amyloid Formation. ACS Chem. Neurosci. 2020, 11 (8), 1178-1191. https://doi.org/10.1021/acschemneuro.0c00069.

(11) Rezaei-Ghaleh, N.; Amininasab, M.; Giller, K.; Kumar, S.; Stündl, A.; Schneider, A.; Becker, S.; Walter, J.; Zweckstetter, M. Turn Plasticity Distinguishes Different Modes of Amyloid- $\beta$ Aggregation. J. Am. Chem. Soc. 2014, 136 (13), 4913-4919. https://doi.org/10.1021/ja411707y.

(12) Kumar, S.; Rezaei-Ghaleh, N.; Terwel, D.; Thal, D. R.; Richard, M.; Hoch, M.; Mc Donald, J. M.; Wüllner, U.; Glebov, K.; Heneka, M. T.; Walsh, D. M.; Zweckstetter, M.; Walter, J. Extracellular Phosphorylation of the Amyloid $\beta$-Peptide Promotes Formation of Toxic Aggregates during the Pathogenesis of Alzheimer's Disease. EMBO J. 2011, $30 \quad$ (11), 2255-2265. https://doi.org/10.1038/emboj.2011.138.

(13) Kumar, S.; Wirths, O.; Stüber, K.; Wunderlich, P.; Koch, P.; Theil, S.; Rezaei-Ghaleh, N.; Zweckstetter, M.; Bayer, T. A.; Brüstle, O.; Thal, D. R.; Walter, J. Phosphorylation of the Amyloid $\beta$-Peptide at Ser26 Stabilizes Oligomeric Assembly and Increases Neurotoxicity. Acta Neuropathol. (Berl.) 2016, 131, 525-537. https://doi.org/10.1007/s00401-016-1546-0.

(14) Pilkington, A. W.; Schupp, J.; Nyman, M.; Valentine, S. J.; Smith, D. M.; Legleiter, J. Acetylation of Aß40 Alters Aggregation in the Presence and Absence of Lipid Membranes. ACS Chem. Neurosci. 2020, 11 (2), $146-161$. https://doi.org/10.1021/acschemneuro.9b00483.

(15) Chalker, J. M.; Gunnoo, S. B.; Boutureira, O.; Gerstberger, S. C.; Fernández-González, M.; Bernardes, G. J. L.; Griffin, L.; Hailu, H.; Schofield, C. J.; Davis, B. Methods for Converting Cysteine to Dehydroalanine on Peptides and Proteins. Chem. Sci. 2011, 2 (9), 1666-1676. https://doi.org/10.1039/C1SC00185J.

(16) Chalker, J. M.; Lercher, L.; Rose, N. R.; Schofield, C. J.; Davis, B. G. Conversion of Cysteine into Dehydroalanine Enables Access to Synthetic Histones Bearing Diverse Post-Translational Modifications. Angew. Chem. Int. Ed. 2012, 51 (8), $1835-1839$. https://doi.org/10.1002/anie.201106432.

(17) Lindstedt, P. R.; Aprile, F. A.; Sormanni, P.; Rakoto, R.; Dobson, C. M.; Bernardes, G. J. L.; Vendruscolo, M. Systematic Activity Maturation of a Single-Domain Antibody with Non-Canonical Amino Acids through Chemical Mutagenesis. Cell Chem. Biol. 2020, 0 (0). https://doi.org/10.1016/j.chembiol.2020.11.002.

(18) Lindstedt, P. R.; Taylor, R. J.; Bernardes, G. J. L.; Vendruscolo, M. Facile Installation of Post-Translational Modifications on the Tau Protein via Chemical Mutagenesis. ACS Chem. Neurosci. 2021, 12 (3), 557-561. https://doi.org/10.1021/acschemneuro.0c00761.

(19) Abelein, A.; Chen, G.; Kitoka, K.; Aleksis, R.; Oleskovs, F.; Sarr, M.; Landreh, M.; Pahnke, J.; Nordling, K.; Kronqvist, N.; Jaudzems, K.; Rising, A.; Johansson, J.; Biverstål, H. High-Yield Production of Amyloid- $\beta$ Peptide Enabled by a Customized Spider Silk Domain. Sci. Rep. 2020, 10 (1), 235. https://doi.org/10.1038/s41598-019-57143-x.

(20) Reddy, G.; Straub, J. E.; Thirumalai, D. Influence of Preformed Asp23-Lys28 Salt Bridge on the Conformational Fluctuations of Monomers and Dimers of Abeta Peptides with Implications for Rates of Fibril Formation. J. Phys. Chem. B 2009, 113 (4), 11621172. https://doi.org/10.1021/jp808914c.

(21) Xiao, Y.; Ma, B.; McElheny, D.; Parthasarathy, S.; Long, F.; Hoshi, M.; Nussinov, R.; Ishii, Y. A $\beta(1-42)$ Fibril Structure Illuminates SelfRecognition and Replication of Amyloid in Alzheimer's Disease. Nat. Struct. Mol. Biol. 2015, 22 (6), $499-505$. https://doi.org/10.1038/nsmb.2991.

(22) Liu, H.; Naismith, J. H. An Efficient One-Step Site-Directed Deletion, Insertion, Single and Multiple-Site Plasmid Mutagenesis Protocol. BMC Biotechnol. 2008, 8 (1), 91. https://doi.org/10.1186/1472-6750-8-91.

(23) Gasteiger, E.; Hoogland, C.; Gattiker, A.; Duvaud, S.; Wilkins, M. R.; Appel, R. D.; Bairoch, A. Protein Identification and Analysis Tools on the ExPASy Server. In The Proteomics Protocols Handbook; Walker, J. M., Ed.; Humana Press: Totowa, NJ, 2005 ; pp 571-607. https://doi.org/10.1385/1-59259-890-0:571. 